\title{
Decarburization Reaction in Ultra-low Carbon Iron Melt under \\ Reduced Pressure
}

Yasuo Kishimoto, Koji Yamaguchi, Toshikazu Sakuraya and Tetsuya FujI

\begin{abstract}
Synopsis :
The kinetics for the decarburization of iron melt in the ultra-low carbon range under reduced pressure were studied, using an induction furnace with a $20 \mathrm{~kg}$ melt. The results obtained are as follows :

1) The decarburization reaction proceeded to less than $5 \mathrm{ppm}$ of carbon, and the decarburization rate constant, $K$, decreased as the carbon content decreased.

2) As the pressure in the chamber decreased, the decarburization rate increased with a carbon content of more than $10 \mathrm{ppm}$. On the contrary, the dependency of decarburization rate on the pressure in the chamber was small with less than $10 \mathrm{ppm}$ of carbon.

3) As the influence of the sulfur content on the decarburization rate was small with a carbon content of more than $10 \mathrm{ppm}$ and the decarburization rates were also not affected by the mass transfer of $\mathrm{CO}$ in the gas phase under the experimental conditions, it is concluded that the decarburization rate was controlled by the mass transfer of carbon in liquid iron.

4) The fact that the decarburization rate with a carbon content of more than $10 \mathrm{ppm}$ was affected by the total pressure of the chamber was explained by the change in interfacial area of the reaction between the gas and liquid phases resulting from $\mathrm{CO}$ boiling in the bulk melt.
\end{abstract}

Key words : kinetics; decarburization ; molten iron; ultra-low carbon steel; RH degassing.

\section{1. 緒言}

冷延鋼板の材料特性の向上のために，極低炭素鋼板の 炭素濃度（以下では $[\mathrm{C}]$ と称する）の低下が望まれてい る. 例えば, $[\mathrm{C}]=30 \mathrm{ppm}$ (質量分率 : 以下同様) の鋼 板に比べて $[\mathrm{C}]<20 \mathrm{ppm}$ の鋼板は伸びなどの加工性が 向上することが報告されている1

極低炭素鋼は，一般に転炉で $[\mathrm{C}]=0.02 \sim 0.04 \%$ で 出鋼した溶鋼を $\mathrm{RH}$ 環流式真空脱ガス装置（以下では $\mathrm{RH}$ と称する) で $[\mathrm{C}]<30 \mathrm{ppm}$ まで真空脱炭して溶製さ れている. RH の脱炭反応速度は $[\mathrm{C}]<30 \sim 50 \mathrm{ppm}$ から 急激に低下することが報告されており ${ }^{23)},[\mathrm{C}]<15 \mathrm{ppm}$ の極低炭素鋼を溶製する際には処理時間が長くなるなど の問題が生じる，そのため極低炭素濃度域での脱炭速度 の向上が望まれているが, 極低炭素濃度域の減圧下の脱。 炭反応に関する研究は実験室規模でもほとんど行われて いない4).
原島ら ${ }^{4)}$ は, $12 \mathrm{~kg}$ の真空誘導溶解炉において減圧下 で[C]がおよそ $600 \mathrm{ppm}$ の溶鉄を $\mathrm{CO} / \mathrm{CO}_{2}-\mathrm{Ar}$ 混合ガ ス吹付けにより $10 \mathrm{ppm}$ 以下まで脱炭する実験を行って いる. しかし，この実験では溶鉄中の酸素濃度（以下で は[0]と称する) は $50 \mathrm{ppm}$ 程度と低く，ガス相から酸 素が供給される条件下で脱炭が行われている，実操業の $\mathrm{RH}$ では極低炭素濃度域では溶鋼の[O]通常 $300 \mathrm{ppm}$ 以上に維持され，酸素はガス相から供給されずに脱炭が 進行している，酸素の供給力法により，両者の脱炭反応 の律速過程が異なる可能性がある.

そこで, 本研究では $20 \mathrm{~kg}$ 真空誘導解炉を用いて $\mathrm{RH}$ と同じ鋼中 $\mathrm{O}$ による脱炭反応を調查し極低炭素濃度域 の脱炭反応機構について検討する。 さらに実操業の $\mathrm{RH}$ における脱炭反応速度との比較を行い, RHにおける極 低炭素濃度域の脱炭反応機構に関する考察を行う。

平成元年 10 月本会講演大会にて発表 平成 3 年 9 月 24 日受付 (Received Sep. 24, 1991)

* 川崎製鉄(株)鉄鋼研究所 (Iron \& Steel Research Laboratories, Kawasaki Steel Corp., 1 Kawasaki-cho Chuo-ku Chiba 260)

*2 川崎製鉄(株)鉄鋼研究所 工博 (Iron \& Steel Research Laboratories, Kawasaki Steel Corp.) 


\section{2. 実 験 方 法}

実験は周波数 $3.0 \mathrm{kHz}$ の高周波真空誘導溶解炉で $20 \mathrm{~kg}$ の鉄を溶解して行った。実験装置の概略図を, Fig. 1 に示卞. るつぼは主として内径 $0.15 \mathrm{~m}$, 高さ $0.2 \mathrm{~m}$ のマグネシアるつぼを用いたが，一部の実験では 内径 $0.12,0.18 \mathrm{~m}$ のるつぼも用いた。実験時の溶鉄は 高純度電解鉄（[S]<5 ppm, [C], [Si], [Mn], [P]は いずれも50 ppm 以下) を用いた。実験は以下に示す手 順で行った.マグネシアるつほ内に高純度電解鉄を装入 しアルゴン雲囲気下で溶解する。溶解後黒鉛と鉄鉱石を 添加し, [C]と [O]を所定の值 ( $[\mathrm{C}]=200 \sim 400 \mathrm{ppm},[\mathrm{O}]$ $=100 \sim 500 \mathrm{ppm}$ ）とする. その後タンク内を減圧し， 所定の圧力に達した時点で直ちにサンプルを採取して実 験の開始時間とした。タン内の圧力は，CO ガス発生 速度の变化にあわせてタンク内に流すアルゴンガスの流 量を変化させることにより士 $1.3 \times 10^{2} \mathrm{~Pa}$ （=1 torr） の精度で一定に保った. 実験中は $\mathrm{Pt} \cdot \mathrm{Rh} 6 \%-\mathrm{Pt} \cdot \mathrm{Rh} 30 \%$ 熱電対を溶鉄に浸漬し所定の温度（主として1873 K) に保持した。

実験中に一定時間ごとに石英管でサンプルを採取し， [C]および[O]の分析を行った，その他の成分（[Si]， $[\mathrm{Mn}],[\mathrm{P}],[\mathrm{S}])$ に関しては実験の前後で変化しない ことを確認している．[C]の分析は試料を電解研磨法に より洗浄した後に, 高感度型炭素分析装置（堀場製作所 EMIA-U511 型）を用いて燃焼赤外線吸収法で行った。

[C]分析装置の標準化はしょ糖を用いて行った.ただ， $[\mathrm{C}]<5 \mathrm{ppm}$ では分析精度が問題となるため，本論文で は $[\mathrm{C}]>5 \mathrm{ppm}$ の範囲の脱炭速度のみ論ずることにす

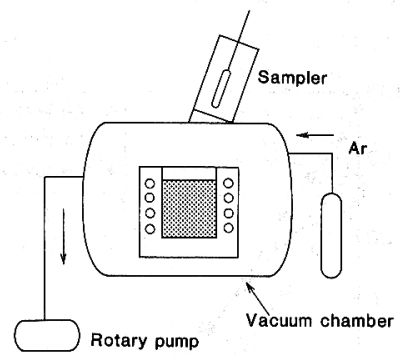

Fig. 1. Schematic diagram of the experimental apparatus.

Table 1. Experimental conditions.

\begin{tabular}{ll}
\hline Metal capacity & $20 \mathrm{~kg}$ \\
Crucible & $\mathrm{MgO} ; 0.12,0.15$ and $0.18 \mathrm{~m}$ diameter \\
Atmosphere & Argon \\
Pressure & $1.3 \times 10^{2}, 1.3 \times 10^{3}, 3.9 \times 10^{3}$ and $6.5 \times 10^{3} \mathrm{~Pa}$ \\
Temperature & $1873 \sim 2023 \mathrm{~K}$
\end{tabular}

る.

その他の主な実験条件を Table 1 に示す.

\section{3. 実 験 結 果}

実験開始時タンク内の減圧中に，圧力がおよそ $1.3 \times$ $10^{4} \mathrm{~Pa}(=100$ torr $)$ 以下となった時点で，溶鉄とるつぼ 壁の接触面で，CO気泡の激しい発生が観察された。さ らに炉内圧力が減少すると Photo. 1 a) に示すように溶 鉄全表面で溶鉄内部からの $\mathrm{CO}$ 気泡の発生が観察され る. 所定の圧力 $\left(1.3 \times 10^{2} \mathrm{~Pa} \sim 6.5 \times 10^{3} \mathrm{~Pa}\right)$ になり, $[\mathrm{C}]=20 \sim 40 \mathrm{ppm}$ の時期にはるつぼ壁と溶鉄の接触面 でのみ $\mathrm{CO}$ 気泡の発生が誰祭される (Photo. $1 \mathrm{~b})$. 実験 開始の約 $10 \mathrm{~min}$ 後 ([C]<15 ppm) には Photo. 1c) に 示すように $\mathrm{CO}$ 気泡の発生は目視では観察されなくな り，溶鉄表面が物理的に乱されることがなくなる。

溶鉄温度 $1873 \mathrm{~K}$, 真空度 $1.3 \times 10^{2} \mathrm{~Pa}$ (=10 torr) に
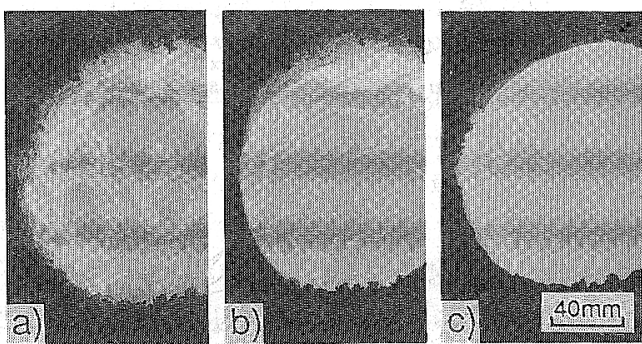

a) $6.5 \times 10^{3} \mathrm{~Pa}$, [C] $>100 \mathrm{ppm}$

b) $1.3 \times 10^{3} \mathrm{~Pa}$, [C] $=25 \sim 35 \mathrm{ppm}$ c) $1.3 \times 10^{3} \mathrm{~Pa},[\mathrm{C}]<10 \mathrm{ppm}$

Photo. 1. Change in the appearance of the molten steel surface under reduced pressure.

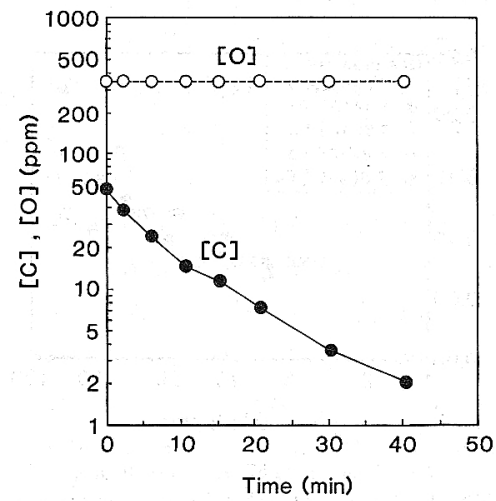

$d=0.15 \mathrm{~m} \quad T=1873 \mathrm{~K} \quad$ Pressure in chamber $=1.3 \times 10^{3} \mathrm{~Pa}$ $[S]=4 \mathrm{ppm}$

Fig. 2. Typical example of change in carbon and oxygen in an iron melt. 
おける脱炭中の $[\mathrm{C}]$ と [O]の挙動を Fig. 2 に示す. [C] は停滞することなく $5 \mathrm{ppm}$ 以下まで低下する. $\ln [\mathrm{C}]$ は $t$ にほぼ比例するようにも見えるが後に述べるように厳 密には一定ではない。

[O]は脱炭中はほとんど変化しておらず，脱炭に使用 される酸素量と同量程度の酸素が溶鉄に供給されてい る. [0]が極端に高い場令は溶鉄と舺火物壁の間にスラ グが観祭された。目視で観察されない場合でも，るつほ 壁・溶鉄の境界に酸化鉄が存在して溶鉄に酸素を供給し ていると思われる†。ただし，酸化鉄が溶鉄表面をおお うことはなかった。 また RH の操業レベルと同じ $[\mathrm{O}]=$ $300 \sim 500 \mathrm{ppm}$ の範囲では，脱炭速度に与える[O]の有 意な影響は認められなかった。鈴木ら ${ }^{5)} の$ 実験でも $[0] /$ $[\mathrm{C}]>1.93$ では脱炭速度は $\mathrm{C}$ の物質移動によって律速 されることが報告されている。これらの結果から，[O]

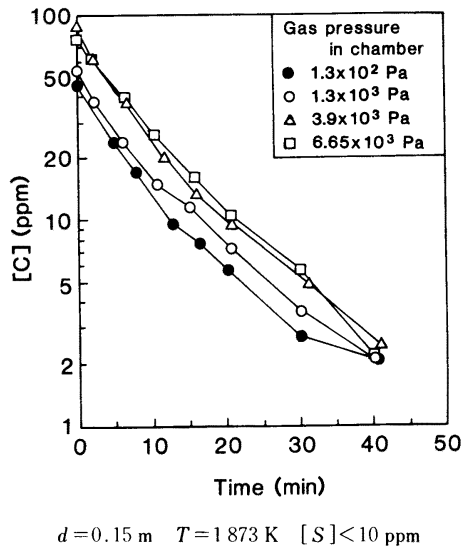

Fig. 3. Influence of pressure in the chamber on the change in carbon content.

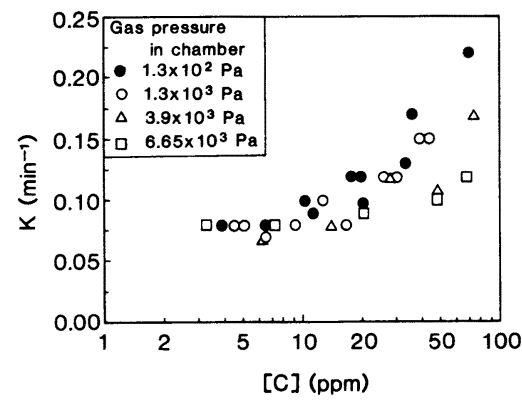

$d=0.15 \mathrm{~m} \quad T=1873 \mathrm{~K} \quad[S]<10 \mathrm{ppm}$

Fig. 4. Relationship between the carbon content and apparent rate constant for decarburization, $K$.

†実験開始以前に添加した鉄鉣石が微少量酸化鉄として溶鉄・るつほ 間に残っていたものと考えられる。
$>100 \mathrm{ppm}$ の条件では $[\mathrm{C}]<50 \mathrm{ppm}$ の領域の脱炭速度は $\mathrm{O}$ に律速されることはないものと判断した。 そこで以 後の実験では[O]は $300 ５ 00 \mathrm{ppm}$ として実験を行っ た。

\section{$3 \cdot 1$ 炉内圧力の影響}

溶鉄温度 $1873 \mathrm{~K}$ で, 炉内圧力を $1.3 \times 10^{2}, 1.3 \times 10^{3}$, $3.9 \times 10^{3}, 6.5 \times 10^{3} \mathrm{~Pa}(=1,10,30,50$ torr $)$ と変化 させた実験の脱炭挙動を Fig. 3 に示す。従来の研究4) と同様に脱炭速度が $\mathrm{C}$ の物質移動に基づく 1 次速度式 で表せると仮定して，各サンプリング区間で(1 1 )式より 脱炭反応のみかけの反応速度定数 $K$, を求めた。結果を Fig. 4 に示す。図中で[C]は各サンプル区間での相乗平 均值である。

$$
K=\ln \left(\frac{[\mathrm{C}]_{i}-[\mathrm{C}]_{e}}{[\mathrm{C}]_{i+1}-[\mathrm{C}]_{e}}\right) /\left(t_{i+1}-t_{i}\right)
$$

なお，用いた記号はすべて末星に示した。 $[\mathrm{C}]_{e}$ は， 実験中の CO ガス発生量 $Q_{\mathrm{CO}}$ と雲囲気用 Ar 量 $Q_{\mathrm{Ar}}$ か らガス相の CO 分压を求めて算出した。しかし，本実 験では Ar を用いて炉内压力を制御していおり， $Q_{\mathrm{Ar}}$ は $Q_{\mathrm{CO}}$ に比較して十分大きくすべての炉内压力において [C] $]_{e}$ は $0.5 \mathrm{ppm}$ 以下であった.

Fig. 4 からわかるように，いずれの炉内压力におい ても $[\mathrm{C}]$ の低下と共に $K$ は低下している。また炉内の 全压を高くするにつれて同一[C]における $K$ が低下し， 特に $[\mathrm{C}]>10 \mathrm{ppm}$ でその傾向が大きい．ただし， [C]< $10 \mathrm{ppm}$ ではその差は小さくなる.

\section{$3 \cdot 2$ 溶鋼温度の影敕}

溶鋼温度を $1873 \mathrm{~K}$ から $2023 \mathrm{~K}$ まで変化させた時の [C]の推移を Fig. 5 に示す。本実験における脱炭速度 は溶鋼温度の影響を強く受ける。 $[\mathrm{C}]=15 \mathrm{ppm}$ での脱

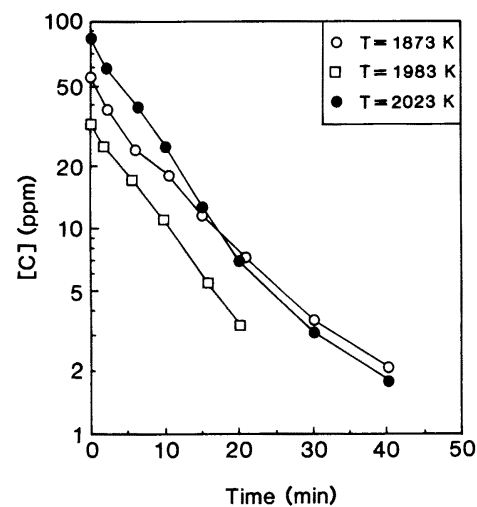

$d=0.15 \mathrm{~m} \quad$ Gas pressure in chamber $=1.3 \times 10^{3} \mathrm{~Pa} \quad[S]<10 \mathrm{ppm}$

Fig. 5. Influence of temperature on the change in carbon content. 
炭速度の見掛けの活性化エネルギーは $104.2(\mathrm{KJ} / \mathrm{mol})$ であった。これは $\mathrm{C} の$ の物質移動の活性化エネルギーと して得られている值 $37.6(\mathrm{KJ} / \mathrm{mol})^{5)}$ より大きな值で ある. 本実験では高周波電源により溶鉄を加熱しており， 高温の実験ほど加熱電力が増大して溶鉄の㩭拌が強化さ れるため, 物質移動係数が増大しているもの无と考えら れる。

\section{$3 \cdot 3 \quad[\mathrm{~S}]$ の影響}

原島ら ${ }^{4)}$ の脱炭実験では界面活性元素である $\mathrm{S}$ の添加 が脱炭反心を阻害することが報告されている。そこで本 実験でも $[\mathrm{S}]$ の影響を調べた．Fig. 6 に $[\mathrm{S}]$ を通常の実 験レベル（4 ppm）から $540 \mathrm{ppm}$ まで変化させた場合の [C]の推移を示した.

$[\mathrm{C}]>10 \mathrm{ppm}$ では $[\mathrm{S}]$ が脱炭速度に与える影響は認め

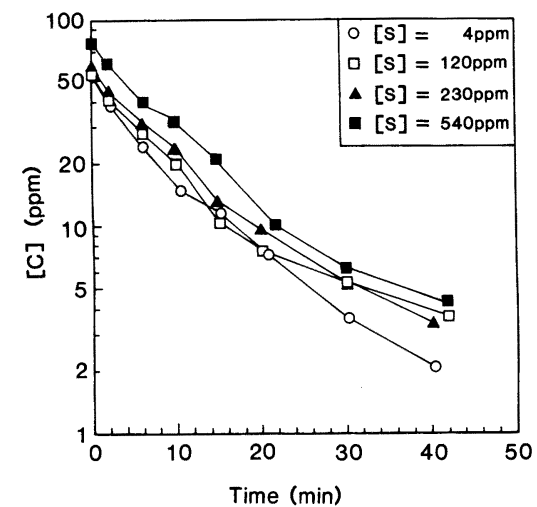

$d=0.15 \mathrm{~m} \quad T=1873 \mathrm{~K} \quad$ Gas pressure in chamber $=1.3 \times 10^{3} \mathrm{~Pa}$ Fig. 6. Influence of sulfur content in iron melt on the change in carbon content.

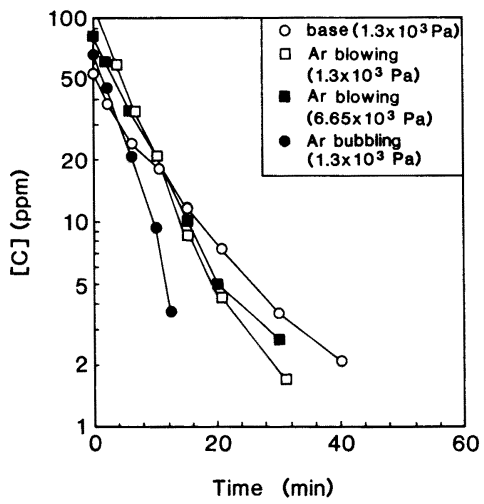

$d=0.15 \mathrm{~m} \quad T=1873 \mathrm{~K} \quad[S]<10 \mathrm{ppm}$ Nozzle dia. $=: 0.003 \mathrm{~m}$ Blown gas flow rate $=1.8 \times 10^{-4}\left(\mathrm{Nm}^{3} / \mathrm{s}\right)$ Bubbled gas flow rate $=8.3 \times 10^{-6}\left(\mathrm{Nm}^{3} / \mathrm{s}\right)$

Fig. 7. Influence of argon blowing and bubbling on the change in carbon content.
られない．ただし $[\mathrm{C}]<10 \mathrm{ppm}$ では $[\mathrm{S}]$ の増加により脱 炭速度が若干低下寸る傾向が認められる。しかし，その 差異は微小である.

\section{$3 \cdot 4$ Ar ガス吹付け実験}

$6.5 \times 10^{3} \mathrm{~Pa}$ および $1.3 \times 10^{3} \mathrm{~Pa}(=50,10$ torr $)$ にお いて, Ar ガスを吹き付ける実験を行った。用いた $\mathrm{Ar}$ の 純度は $99.999 \%$ (体積分率) である。ノズルと溶鉄表面 の距離は 0.04 0.05 m とした.ガス吹付けのない場合 と比較して結果を Fig. 7 に示す. Ar ガス吹付けによっ て極低炭素濃度域の脱炭速度が増大寸ることがわかる。

さらに真空度，ガス流量，ランス高さやノズル口径等 を変化させてガスを吹き付けて実験を行ったが，脱炭速 度には差異は認められなかった。これらのガス吹付けの 条件の変更によりガス側の物質移動の抵抗が変化するこ とを考えるとガス吹付けの効果はガス側の物質移動の抵 抗の減少では説明できない，また，溶鉄の山みの変化に よる気・液界面積の増加率もわずかであり，ガス吹付け の効果は気・液界面積の増加でも説明できない。

さらに，ガス吹付け時の $1 / 20$ 倍以下の流量， $8.3 \times$ $10^{-6}\left(\mathrm{Nm}^{3} / \mathrm{s}\right)$ のガスを浸漬ノズルより吹きこむ実験を 行った. 結果を Fig. 7 中に示す.ガス吹きこみの場合 はガス量は少なくてもガス吹付けの場合以上の脱炭促進 効果が得られた。

ガスの吹付け条件が脱炭速度に影響を及ぼさないこ と，およびガス吹込みの実験結果から，ガス吹付けによ る脱炭促進効果は, 溶鋼の流動が変化して液側物質移動 係数が増加したことによるものと考えられる.

\section{4. 考察}

\section{$4 \cdot 1$ 耐火物との反応の影響}

天野ら7)の $\mathrm{Ar}$ 䨌囲気下のるつぼ溶解法での脱炭実験 や韓 ${ }^{8)}$ の $\mathrm{Ar}^{-} \mathrm{O}_{2}$ 混命ガス吹付けによる脱炭実験では, るつほ耐火物の酸素が解離し，耐火物と溶鉄の界面で脱 炭が進行することが報告されている.

るつぼ舨火物との反応によって脱炭反心が進行すると すると, 反応界面積はるつぼとの接触面積に比例し，る つぼ直径， $d$ に比例すると考えられる ${ }^{\dagger 2}$ ，一方，溶鉄表 面あるいは溶鉄内部で一様に脱炭反応が進行する場令に は反応界面積は溶鉄の横断面積に比例し $d^{2}$ に比例す る.そこで，るつぼ内径を $0.12 \mathrm{~m}, 0.15 \mathrm{~m}, 0.18 \mathrm{~m}$ と変 化させた実験での $d^{2}$ と $K$ の関係を $[\mathrm{C}] て ゙$ 層別して Fig. 8 に示す. $[\mathrm{C}]=40 \mathrm{ppm}$ 抢よび $[\mathrm{C}]=10 \mathrm{ppm}$ では，K

†2 本研究の対象である楩低览素濃度域では, 後述するように $\mathrm{CO}$ 父泡の発生可能な溶鉄深さは限られており,ここでは, 灯底部分 の菂火物-溶鉄間での CO 生成はないものとした。 
は $d^{2}$ にほぼ比例しているが, $[\mathrm{C}]=20 \mathrm{ppm}$ では $K$ は $d^{2}$ には比例しておらず，むしろ $d$ に比例している。

また, Photo. $1 \mathrm{a}) \sim \mathrm{c})$ に示したように本実験では, [C] $>40 \sim 50 \mathrm{ppm}$ では $\mathrm{CO}$ 気泡がるつぼ内溶鉄の全面から 発生しているが, [C]の低下に従いるつぼ-溶鉄の界面 のみで $\mathrm{CO}$ 気泡が発生するようになる。 さらに $[\mathrm{C}]$ が $10 \mathrm{ppm}$ 以下まで低下すると $\mathrm{CO}$ 気泡の発生が観察され なくなる.この観察結果と Fig. 8 より， [C] $]=40$ ppm では溶鉄内部が, $[\mathrm{C}]=20 \mathrm{ppm}$ では溶鉄ーるつほ間の界 面が，それぞれ CO 気泡の主な発生サイトであり，そ の結果 $[\mathrm{C}]=40 \mathrm{ppm}$ では $K$ は $d^{2} に,[\mathrm{C}]=20 \mathrm{ppm}$ で は $K$ は $d$ に比例するものと考えられる. [C]=10 ppm では後に考察するように CO 気泡は溶鉄内部では発生 せず，溶鉄表面でのみ脱炭が進行するため $K$ は $d^{2} に$ 比例するものと考えられる.

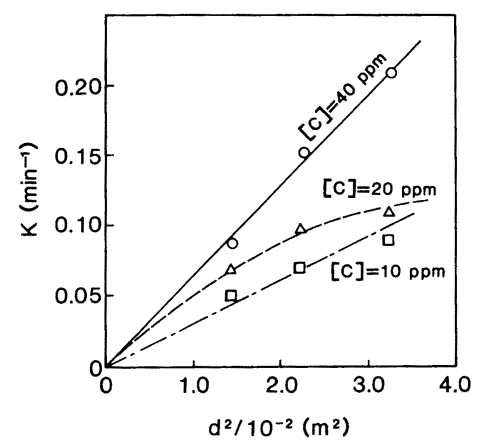

Crucible diameter $=0.12 \mathrm{~m} \quad 0.15 \mathrm{~m}$ and $0.18 \mathrm{~m} \quad T=1873 \mathrm{~K}$ Gas pressure in chamber $=1.3 \times 10^{3} \mathrm{~Pa} \quad[S]<10 \mathrm{ppm}$

Fig. 8. Relationship between $d^{2}$ and $K$ for various carbon contents.

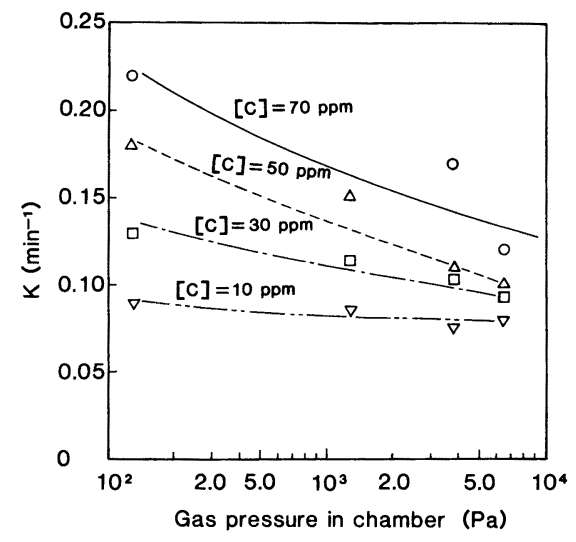

$d=0.15 \mathrm{~m} \quad T=1873 \mathrm{~K} \quad[S]<10 \mathrm{ppm}$

Fig. 9. Relationship between the pressure in chamber and the apparent rate constant for decarburization, $K$.
なお本実験のように[O]が高い実験では，天野ら ${ }^{7) や ~}$ 韓ら ${ }^{8)}$ の実験と異なり耐火物からの酸素供給速度が脱炭 反応を律速するとは考えられず， [C] $=20 \mathrm{ppm}$ で $K$ が $d$ に比例するのは, 耐火物と溶鉄の界面が $\mathrm{CO}$ 気泡の発 生サイトとなるためと考えられる.

\section{$4 \cdot 2$ 律速過程の考察}

本実験における脱炭友心の律速過程としては以下の 3 過程が考えられる.

a)溶鉄-ガス界面への溶鉄側の $\mathrm{C}$ の物質移動 ${ }^{\dagger 3}$

b)界面における化学反忘

c) 溶鉄-ガス界面からガス側への CO の物質移動

原島ら ${ }^{4)}$ は $[\mathrm{C}]=10 \sim 200 \mathrm{ppm} の$ 極低 $[\mathrm{C}]$ 範囲で脱炭速 度が 1 次反応の速度式に従い，しかも $\mathrm{S}$ の添加により 脱炭速度が低下寸ることから, 脱炭反応が CO の生成 反応と液側 $\mathrm{C}$ の物質移動の混合律速と仮定して矛盾な く説明できるとしている.

しかし，本実験では Fig. 6 に示すように脱炭速度の $[\mathrm{S}]$ 依存性は $[\mathrm{C}]>10 \mathrm{ppm}$ ではほとんど認められないこ とから，b）の CO の生成反応は律速過程にならないと 考えられる. 天野ら ${ }^{7)}$ も低炭素濃度域 ([C]<400 ppm)

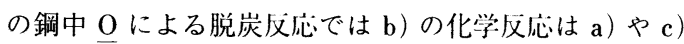
の反応に比べて十分速く律速過程にならないことを報告 している.

溶鉄中の $\mathrm{O} に よ り$ 脱炭が進行する本実験の場合は溶 鉄内部で $\mathrm{CO}$ 気泡が生成して脱炭が進行するが, 原島 ら ${ }^{4)}$ の実験では溶鉄表面のみで脱炭が進䘕すると考えら れる. S は表面活性元素であり，溶鉄表面で脱炭反応 が進行する原島らの実験では $[\mathrm{S}]$ の影響が大きく現れた ものと思われる．本実験でも $[\mathrm{C}]<10 \mathrm{ppm}$ の極低炭素 濃度域では $[\mathrm{S}]$ の影響が現れるのは，[C]の低下によっ て脱炭反応が溶鉄表面のみで進行するようになるためと 考えられる.

以上述べた理由から, 本実験の場合は $[\mathrm{C}]>10 \mathrm{ppm}$ では化学反応が脱炭反応の律速過程となっていないもの と判断される.

Fig. 9 に炉内圧力を変化させた場合の炉内压力と $K$ の 関係を [C] で層別して示す. $[\mathrm{C}]=10 \mathrm{ppm}$ では $K$ は炉 内圧力によらずほぼ一定であるが, [C]>10 ppm では炉 内圧力が減少するほど $K$ が増大する.ガス側の物質移動 に対する抵抗は炉内圧力が減少するに従い減少する。 従って Fig. 9 の結果は, COの物質移動が脱炭反心吣 速過程の一つとなっており, 炉内压力の変化によりガス

$\dagger 3$ 本奏験の条件では, [O]は [C]に比べて数倍仔在するため, 鈴木 らの実験結果に従い，液側の物質移動は C の物質移動に律速さ れるとした。 
側の抵抗が变化したことによる可能性もある.

Fig. 10 に炉内圧力を变化させた時の [C]と脱炭速度 の関倸を示す. [C]<10 ppm の脱炭速度はいずれの炉 内圧力でもほほ同一で[C]に比例しており, 液側 $\mathrm{C} の$ 物質移動に律速されていることがわかる。この結果から 液側 $\mathrm{C}$ の物質移動で決定される脱炭速度は, Fig. 10 中 の実線で表されるものと考えられる。

さて, 脱炭反応が溶鉄およびガスの両濃度境界層中の 物質移動の混合律速の場合, ガス側 $\mathrm{CO}$ 分圧 $P_{\mathrm{CO}}{ }^{g} \fallingdotseq 0$, 溶鉄-ガス界面の $[\mathrm{O}],[\mathrm{O}]_{\mathrm{s}} \doteqdot[\mathrm{O}]$ の仮定の下に, 脱炭 速度を求めると次式が得られる7).

$$
-\frac{d[\mathrm{C}]}{d t}=\frac{a}{V}\left\{\frac{1}{\frac{1}{k_{l}}+\frac{R T}{\alpha k_{g} K '[\mathrm{O}]}}\right\}[\mathrm{C}] \cdots \cdots(2)
$$

( 2 )式は, 溶鉄およびガスの両濃度境界層中の物質移 動の混合律速の場合の脱炭速度は, 液側 $\mathrm{C}$ の物質移動 のみで決定される脱炭速度（( 2$)$ 式で $k_{g}$ を無限大とし た場合）より常に小さくなることを示している.しかし， Fig. 10 より明らかなように，[C]>10 ppm での脱炭速 度は炉内圧力の減少に従い液側 $\mathrm{C}$ の物質移動で決定さ れる脱炭速度 (Fig. 10 中の実線) より増加している. このことは本実験における脱炭速度の圧力依存性はガス 側の抵抗の変化では説明できないことを示している.

減圧下の $k_{g}$ についての研究はなく今回の実験におけ る $k_{g}$ を定量的に求めることは困難であるが, 谷口ら ${ }^{9)}$ の気相内物質移動係数の実験式を用いて $k_{g}$ を試算する と $1.33 \times 10^{2} \mathrm{~Pa}$ で $k_{g}=1.09(\mathrm{~m} / \mathrm{s}), 6.65 \times 10^{3} \mathrm{~Pa}$ で $k_{g}$ $=0.388(\mathrm{~m} / \mathrm{s})$ を得た. [C] $<10 \mathrm{ppm}$ の脱炭速度から求 めた $a k(=\mathrm{KV} / 60)$ と溶鉄の横断面積 $S$ の比, $a k / S$ が 液側 $\mathrm{C}$ の物質移動係数 $k_{l}$ と等しいと考えて, (2)式よ

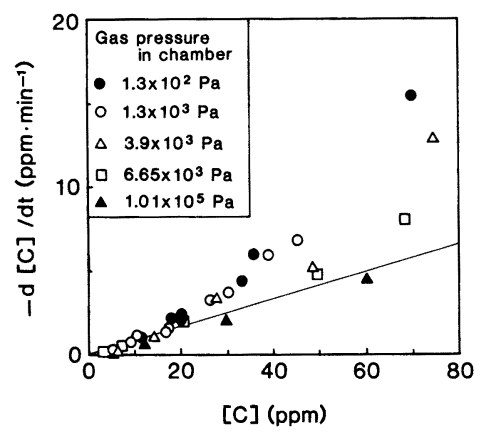

$d=0.15 \mathrm{~m} T=1873 \mathrm{~K} \cdot[S]<10 \mathrm{ppm} ;$ closed triangular symbols represent experiments with argon blown at a flow rate of $4.0 \times 10^{-4}\left(\mathrm{Nm}^{3} / \mathrm{s}\right)$

Fig. 10. Relationship between the carbon content and decarburization rate, $-d[\mathrm{C}] / d t$.
り a）と c）の混合律速の場合の脱炭速度を求めると液 側 $\mathrm{C}$ の物質移動のみが律速過程とした場合の脱炭速度 に比較して，0.980～0.993 倍となる ${ }^{\dagger 4}$. すなわち，本 実験下では脱炭速度に及ぼすガス側の抵抗の影響は微小 であると推察される.

以上の検討から，本実験における脱炭反応は溶鉄側の $\mathrm{C}$ の物質移動が律速となっており，今回の炉内压力の 脱炭速度におよぼす影響はガス側の抵抗の変化では説明 できないことがわかる.

\section{$4 \cdot 3 \mathrm{CO}$ ボイリングの効果}

本実験では大気圧下での $\mathrm{CO}_{2}$ ガスなどの吹付けによ る脱炭反応とは異なり溶鉄内部で $\mathrm{CO}$ 生成が生じ得る. 古典的な核生成理論 ${ }^{10)} に$ 従えば, CO 気泡が生成叮能な 溶鉄内部の深さ, $h$ は, 次式で表せる.

$$
P_{r}=P_{v}+\rho_{l} g h+2 \gamma / r \leqq P_{\mathrm{CO}}
$$

( 3 )式は $[\mathrm{C}]$ の低下に従って溶鉄の $[\mathrm{C}],[\mathrm{O}]$ と平衡 する CO ガス分圧, $P_{\mathrm{CO}}$ が低下すると溶鉄内部で CO 気泡が生成叮能な領域（深さ）が減少することを意味し ている. 例えば $\mathrm{CO}$ 気泡の半径, $r=0.01 \mathrm{~m}$ の場合には, $h$ と $[\mathrm{C}]$ の関係は Fig. 11 に示すような関係になる.こ こで $\gamma=1.7(\mathrm{~N} / \mathrm{m})^{11)},[\mathrm{O}]=400 \mathrm{ppm}$ とした.

[C]の低下に従い $\mathrm{CO}$ ガス気泡が発生できる深さ， $h$ は減少し，しだいに溶鉄内部では $\mathrm{CO}$ 気泡が発生しな くなることがわかる．また炉内压力， $P_{v}$ ，によっても $h$ が変化することもわかる，従って，本実験で炉内压力が 脱炭速度に大きな影響を与える理由も $\mathrm{CO}$ 気泡発生の 領域の変化によるものと考えられる.すなわち，Fig. 4 および Fig. 10 からわかるように，炉内圧力が低いほど

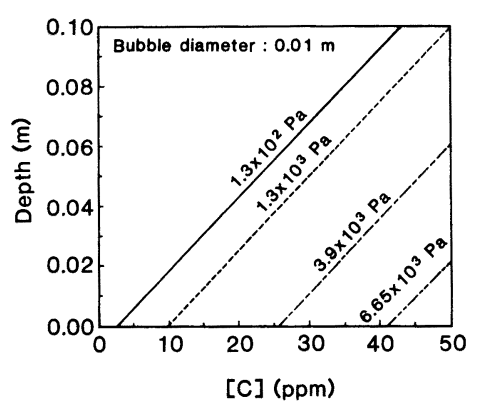

Fig. 11. Relationship between carbon content and depth of zone where nucleation of carbon monoxide bubbles can occur under various pressures.

$\dagger 4[\mathrm{C}]<10 \mathrm{ppm}$ では, 脱炭反応は溶鉄の表面のみで進行すること から溶鉄の横断面積 $S$ が反応界面積 $a$ と等しいとした。ま， ここでは, 溶鉄自由表面, 溶鉄一酎火物, 溶鉄内部の反応サイト のいずれにも CO の物質移動の抵抗を考えているので，ガス側 の抵抗は最も大きく見皘もっていることになる。 
低 $[\mathrm{C}]$ まで脱炭速度は $[\mathrm{C}]<10 \mathrm{ppm} に お け る$ 脱炭速度 (Fig. 10 中実線) より大きい。これは炬内圧力が低く なるほど低 $[\mathrm{C}]$ まで溶鉄内部に $\mathrm{CO}$ 気泡の発生が可能な 領域が存在するため反応の界面積が大きくなり, 脱炭速 度が増加するためと考えられ，Fig. 11 の結果と定性的 に一致する。また，目視およびビデオ撮影においても炉 内圧力が低いほど極低炭素濃度域まで $\mathrm{CO}$ 気泡が発生 するのが観察された．[C] が低下すると溶鉄内部におい て CO 気泡が発生せず脱炭反応は溶鉄表面でのみ進行 するため反応界面積が一定となる ${ }^{\dagger 5}$. その結果 $[\mathrm{C}]<10$ ppm での脱炭速度は[C]に比例するようになる.

$\mathrm{CO}$ 気泡発生領域の変化により脱炭速度が変化すると すると，炉内圧力が高い場合には $[\mathrm{C}]$ 㙜くても溶鉄内 部での $\mathrm{CO}$ 気泡が発生しなくなり, 脱炭速度は $[\mathrm{C}]$ に比 例することが予想される。 そこで大気压において Arを 吹き付けて脱炭する実験を行い脱炭速度と [C]の関係を 求め, Fig. 10 中に示した。この場合, 脱炭反応サイト は主として溶鉄表面であり CO ガスのボイリングは観 察されなかった。この時の脱岸速度は 1 次の速度式で近 似でき, 比較的高 $[\mathrm{C}]$ 域に沶いても脱炭速度定数は低值 となった。

\section{$4 \cdot 5$ 工業規模の脱ガス設備での脱炭速度との比較}

Fig. 12 に，千葉 3 製鎆 $260 \mathrm{tRH}$ における[C]と，真 空槽内の $\underline{\mathrm{C}}$ 物質移動の容量倸数 $a k$ を真空槽横断面積 $S$ で除した $a k / S$ の関係を示した。ここで $a k$ について は, 住田ら ${ }^{2)}$ の解析と同じ手法で求めた.

[C]の低下に従い，急激に $a k$ が低下することがわか る.この傾向は種々の $\mathrm{RH}$ で共通に観察される ${ }^{13)}$. 真 空槽内の溶鉄表面が主な脱炭反応サイトとすると， $a k / S$ は溶鋼側の $\mathrm{C}$ の物質移動係数 $k_{l}$ に相当する. し かし, 高周波炉に打ける低炭素濃度域の脱炭反応での $k_{l}=2 \sim 5 \times 10^{-4}(\mathrm{~m} / \mathrm{s})^{4 / 5) 7) 12)}$ と比較して, [C $] \geqq 30 \mathrm{ppm}$ での $\mathrm{RH}$ の $a k / S$ は数十倍も高い值を示している.

内部からの $\mathrm{CO}$ 気泡発生が生じない $[\mathrm{C}]<10 \mathrm{ppm}$ で は $a k / S$ が本るつほ実験で得られる值に近づいていく事 実と考えあわせると, RH での $a k / S$ の大きな $[\mathrm{C}]$ 依存 性は溶鉄内部の $\mathrm{CO}$ 気泡発生と密接な関係にあると推 定される。ただしるつほ実験に比べて RH での $a k / S$ の [C]依存性は大きい.

$\mathrm{RH}$ では環流量の増加により $a k$ が著しく増加する ${ }^{13)}$.

†5 4.1 で示したように[C]の低下に従い, CO 気泡の発生サイトが 溶鉄内部全体から射火物一溶鉄間に变化する.これは[C]の低下に 従い核生成が溶鉄内部で困難となり核生成が率易な耐火物一溶鉄 間のみで CO 気泡が生成するようになるためと考えられる。たた し, $\mathrm{CO}$ 気泡の径の決定や $\mathrm{CO}$ 気泡発生機構の群細な検詿は今後 の課題である.

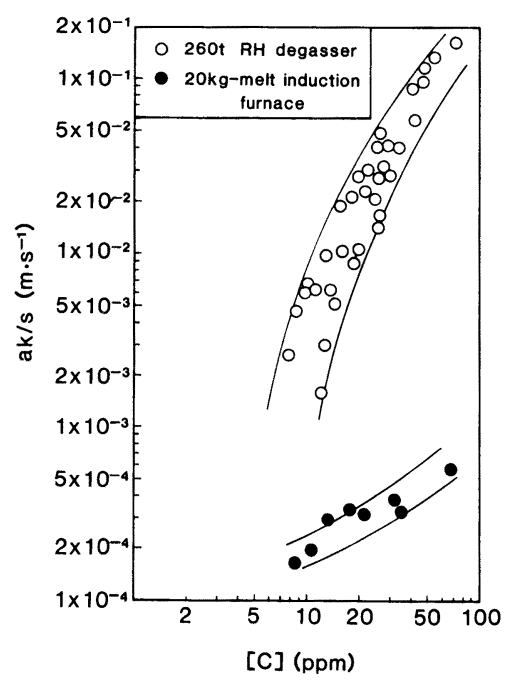

Fig. 12. Relationship between the carbon content and $a k / S$. (260t RH degasser in Chiba Works and an induction furnace with a $20 \mathrm{~kg}$ iron melt (gas pressure in chamber $=1.3 \times 10^{3} \mathrm{~Pa}$ ))

この理由は, 気液界面積の増加か環流量増加により生じ ているものと考えられる. KUWABARA ら ${ }^{3)}$ は, 100 tRH に おいてスプラッシュ高さと $[\mathrm{C}]$ の関係を測定し，[C]> $50 \mathrm{ppm}$ では 2 3 m もの高さにスプラッシュが飛ぶこ と,および $[\mathrm{C}]$ の低下と共にスプラッシュ高さが隇少す ることを報告している．スプラッシュにより生じた液滴 は同一体積において大きな界面積を有する上に，溶鉄静 压の影響を受けないため内部より容易に $\mathrm{CO}$ 気泡が生 成すると考えられる.

RH において $[\mathrm{C}]$ 䯩いほど，環流量が大きいほど， るつぼ実験に比べて大きな $a k / S$ の值を示すのはこうし たスプラッシュにより大量に生じた液滴が存在すること によるものと考えられる ${ }^{+6}$. RH に扔ける $a k$ と真空槽 内の横断面積 $S$,の相関が小さい事実 ${ }^{13)}$ も，スプラッ シュにより反応界面積が決定されていることを示唆して いるものと考えられる．また RHでの $a k$ の大きな $[\mathrm{C}]$ 依存性も, $\mathrm{CO}$ 発生量の減少に伴ってスプラッシュ量が 隇少することにより反界面積が減少するためと考えら れる

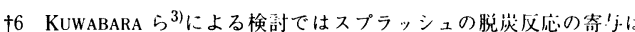
小さいとしているが、これは液滴の表面のみで脱炭反応が生じる と仮定し溶鉄内部の CO 生成を考虑していないためと思われる.

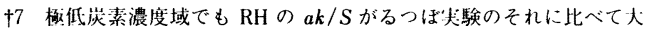
きい事実もスプラッシュ発生曼に起因する反伈界面皘の違いによ ると考えられる。しかしより詳細な検討には RH 真究槽内のCO 発生機構や流動現象の把握が必要である. 
最後に RH での極低炭素濃度域の脱炭速度向上策を 考える．環流量の増加により $\mathrm{RH} て ゙ の ~ a k$ の増加が可能 であるが RH で環流量を増大させるには浸漬管径を拡 大させる必要があり設備上の限界がある。 MuRayama $ら^{14)}$ は, 気液界面積と攪拌力の増加を狙って $250 \mathrm{tRH}$ に抢いて真空槽内に $\mathrm{Ar}$ を $10\left(\mathrm{Nm}^{3} / \mathrm{min}\right)$ 以上も吹きこ み，極低炭素濃度域のみ脱炭速度が向上することを報告 している. しかしその効果は小さい. 羽口数の影響がな いことから $\mathrm{Ar}$ 気泡による界面積の増加よりもスプラッ シュ増大による界面積の増加効果が大きいと思われる。

浅井 ${ }^{15)}$ は, 気・液間物質移動速度の増加には反応界面 積の増加が最も重要であり，そのために化学反応の利用 による微小気泡の生成を提案し，酸化物の利用を考えて いるが，極低炭素濃度域では酸化物は反忍しないので有 効とは考えがたく，可溶性ガスの利用 ${ }^{2) 16)}$ が有効と考え られる．可溶性ガス利用による極低炭素濃度域での脱炭 促進技術については今後さらに検討を行う。

\section{5. 結言}

$20 \mathrm{~kg}$ 真空誘導溶解炉を用いて減圧下での鋼中酸素に よる極低炭素濃度域の脱炭反応機構を研究し，以下の結 果を得た。

1 )脱炭反応は $5 \mathrm{ppm}$ 以下まで進行するが, 脱炭反応 が一次反応であると仮定して得られる脱炭反応速度定数 $K$ は $[\mathrm{C}]$ の低下につれて低下する.

2 )炉内全圧が減少するにつれ[C]>10 ppm の脱炭速 度は増加するが, [C]<10 ppm では圧力の影響は小さ くなる.

3 )脱炭速度が $[\mathrm{S}]$ に影響を受けないこと及びガス側 の物質移動の抵抗が本実験では小さいことから, 本実験 での律速過程は液側 $\mathrm{C}$ の物質移動であると判断される.

4 )炉内压力の減少により [C]>10 ppm の脱炭速度が 増加する理由は, 溶鉄内部での CO 気泡の生成が増加 し，ボイリングにより気液界面積が増加するためと考え られる。

5 ) RH における極低炭素濃度域の脱炭速度の低下も $\mathrm{CO}$ 気泡発生の機構に起因する反㐫界面積の減少によっ て起こると考えられる. そのため, 極低炭素濃度域の脱 炭速度の向上には反応界面積の増加を図る必要がある。

本研究の遂行にあたり，極低 $[\mathrm{C}]$ の分析に協力してい ただいた川鉄テクノリサーチ(株) 総合検査・分析セン ター針間矢宣一氏に感謝いたします。

\section{記 号}

$a:$ 溶鉄-ガスの界面積 $(\mathrm{m}), a k$; 脱炭反心の容量係数 $\left(\mathrm{m}^{3} / \mathrm{s}\right),[\mathrm{C}]_{e}$ : ガス相の $\mathrm{CO}$ 分压と平衡する $[\mathrm{C}](\mathrm{ppm})$, $[\mathrm{C}]_{i}$; サンプリング点 $i$ における $[\mathrm{C}](\mathrm{ppm}), d$; るつほ 直径 $(\mathrm{m}), g$; 重力加速度 $\left(\mathrm{m} / \mathrm{s}^{2}\right), h ; \mathrm{CO}$ 気泡が発生 可能な溶鉄内の深さ $(\mathrm{m}), K$; 脱炭反応の見掛けの反応 速度定数 $(1 / \mathrm{min}), K^{\prime} ; \mathrm{C}-\mathrm{O}$ 反応の平衡定数, $k_{g} ; \mathrm{CO}$ ガスの物質移動係数 $(\mathrm{m} / \mathrm{s}), k_{l}$; 溶鉄側の $\mathrm{C}$ の物質移 動係数 $(\mathrm{m} / \mathrm{s}), P_{\mathrm{CO}}{ }^{g}$; ガス側 $\mathrm{CO}$ 分圧 $(\mathrm{Pa}), P_{\mathrm{CO}}$; 溶 鉄中の $[\mathrm{C}]$ と $[\mathrm{O}]$ に平衡する $\mathrm{CO}$ 分压 $(\mathrm{Pa}), P_{r}$; 気泡 径 $r$ の気泡の压力 $(\mathrm{Pa}), P_{v}$; 雲用気圧力 $(\mathrm{Pa}), Q_{\mathrm{CO}}$; 脱炭時の $\mathrm{CO}$ 発生量 $\left(\mathrm{Nm}^{3} / \mathrm{s}\right), Q_{\mathrm{Ar}}$; 炉内圧力調整用 $\mathrm{Ar}$ 流量 $\left(\mathrm{Nm}^{3} / \mathrm{s}\right), R$; 気体定数 $(\mathrm{J} / \mathrm{mol} / \mathrm{K}), r ; \mathrm{CO}$ 気 泡径 $(\mathrm{m}), S$ : るつぼあるいは RH の真空槽内の溶鉄の 横断面積 $\left(\mathrm{m}^{2}\right), T$; 溶鉄温度 $(\mathrm{K}), t_{i} ;$ サンプリング区 間 $i$ における時間 $(\mathrm{min}), \quad V$; 溶鉄の体積 $\left(\mathrm{m}^{3}\right), \alpha$; 係 数 $\left(=1.732 \times 10^{1}\left(\mathrm{~mol} \mathrm{~Pa} / \mathrm{m}^{3} / \%\right)\right), \gamma$; 表面張力 $(\mathrm{N} / \mathrm{m})$, $\rho_{l} ;$ 溶鉄の密度 $\left(\mathrm{kg} / \mathrm{m}^{3}\right)$

添え字 : $s$; 溶鉄-ガス界面, $g$; ガス, $l$; 液

\section{文献}

1）角山浩三，小原隆史，佐藤 進，阿部英大，柴崎 治， 上杉暢彦: 川崎製鉄技報，22（1990），p. 173

2 ) 住田則夫, 藤井徹也, 小口征男, 森下 1:，数土文大： 川崎製鉄技報, 15 (1983), p. 152

3 ) $T$. Kuwabara, $K$. Umezawa, $K$. Mori and $H$. Watanabe: Trans. Iron Steel Inst. Jpn., 28 (1988), p. 305

4 ) 原島和海, 溝口庞三, 梶岡博幸: 鉄と鋼, 74 (1988), p. 449

5 ) 鈴木 鼎, 森一美, 北川 融, 柴山卓真: 鉄と鋼, 62 (1976), p. 354

6 ) V. H. KNUPPEL and F. OETERS :Arch. Eisenhüttenwes., 33 (1962), p. 729

7 ) 天野和男, 伊藤公允, 坂尾弘: 鉄と鋼, 62 (1976), p. 344

8 ) 韓 業鞎, 澤田 義, 加藤将和, 佐野正道: 鉄と鋼, 77 (1991), p. 377

9 ) 谷口尚司, 菊地 淳, 前田四郎: 鉄と鐦, 62 (1976), p. 191

10) F. D. RichardSon: Physical Chemistry of Melts in Metallurgy (1974), p. 455 [Academic Press, London]

11）溶鉄·溶涬の物性傾便覧（日本鉄銅協会編）（1972）, p. 125

12）野村宏之, 森一美: 鉄と鋼, 58 (1972), p. 29

13) $K$. Yamaguchi, $Y$. Kishimoto, $T$. Sakuraya, $T$. Fuji, $M$. ARATANI and H. NishiKaWA: ISIJ Int., 32 (1992), p. 126

$14) N$. Murayama, $Y$. Mizukami, $K$. Azuma, $S$. Onoyama and $T$. ImAI : The 6th International Iron \& Steel Congress, Nagaya, Japan, vol 3 (1990), p. 151

15）浅井滋生：第 $100 \cdot 101$ 回西山記念講座（日本鉄鋼協会編） (1984), p. 66

16）沖本伸一, 渡辺 敬, 長谷川輝之, 寺田 修, 松野英寿, 菊地良輝: 材料とプロセス，3 (1990)，p. 247 